This item was submitted to Loughborough's Research Repository by the author.

Items in Figshare are protected by copyright, with all rights reserved, unless otherwise indicated.

\title{
From 'shadowy cabal' to new profession: networks of cooperation and competition in UK Higher Education fundraising
}

PLEASE CITE THE PUBLISHED VERSION

http://dx.doi.org/10.1177/0263774X15614681

PUBLISHER

(c) SAGE Publications Ltd

VERSION

AM (Accepted Manuscript)

\section{PUBLISHER STATEMENT}

This work is made available according to the conditions of the Creative Commons Attribution-NonCommercialNoDerivatives 4.0 International (CC BY-NC-ND 4.0) licence. Full details of this licence are available at: https://creativecommons.org/licenses/by-nc-nd/4.0/

\section{LICENCE}

CC BY-NC-ND 4.0

\section{REPOSITORY RECORD}

Warren, Adam, Michael Hoyler, and Morag Bell. 2019. "From 'shadowy Cabal' to New Profession: Networks of Cooperation and Competition in UK Higher Education Fundraising". figshare.

https://hdl.handle.net/2134/17783. 
From 'shadowy cabal' to new profession: Networks of cooperation and competition in UK Higher

Education fundraising

Dr Adam Warren*

Department of Geography

Loughborough University

Loughborough, Leicestershire

LE11 3TU

A.P.Warren@lboro.ac.uk

Michael Hoyler

Department of Geography

Loughborough University

Loughborough, Leicestershire

LE11 3TU

M.Hoyler@lboro.ac.uk

Professor Morag Bell

Department of Geography

Loughborough University

Loughborough, Leicestershire

LE11 3TU

M.Bell@lboro.ac.uk

*Corresponding author 


\title{
From 'shadowy cabal' to new profession: Networks of cooperation and competition in UK Higher \\ Education fundraising
}

\begin{abstract}
Recent UK government policy initiatives have encouraged universities to seek funding from philanthropic sources. Yet, there has been little investigation into the work of the emergent Higher Education professionals expected to deliver this additional income. In this paper, we consider the role of professional networks in facilitating knowledge exchange amongst university fundraisers. Through interviews with senior UK philanthropy professionals in the 1960s universities, we identify significant variations amongst professional networks and peer groups. We argue that professional networks are multi-layered and often exclusionary. Yet, among participants, these associations provide both open spaces of learning and a means of achieving competitive advantage. Moreover, the networks permit university philanthropy professionals to develop new distinctive identities, transcending the institutional and locational setting of their employing organisations. This paper advances theoretical debates on the complexities of knowledge exchange across spatial scales and the role of these networks in the establishment of a new profession.
\end{abstract}

Keywords: Higher Education, Networks, Profession, Knowledge Exchange, Neoliberalism 


\section{From 'shadowy cabal' to new profession: Networks of cooperation and competition in UK Higher Education fundraising}

\section{Introduction}

In April 2014, the Higher Education Funding Council for England (HEFCE) published An Emerging Profession: The Higher Education Philanthropy Workforce (HEFCE, 2014). This review of the UK fundraising workforce (hereafter, 'Workforce Review') - conducted at a time of significant state withdrawal from HE funding, particularly in English universities - called for universities to:

...take ownership of finding ways to grow and develop the fundraising workforce, for example by allowing their staff to help other institutions and playing a role in raising the profile of fundraising in HE (HEFCE, 2014: 13).

The Workforce Review represents the most recent response to a succession of UK government policy initiatives extending over a decade aimed at ensuring universities 'take responsibility for their own strategic and financial future' (DfES, 2003: 8; see also; DCSF, 2007; DfES, 2004). Specifically, Higher Education Institutions (HEIs) were expected to provide incentives to ‘build up endowments' (DfES, 2003: 9) and, more broadly, to promote philanthropic giving (Cabinet Office, 2011; DCSF, 2007; DfES, 2004). Accordingly, the HEFCE-commissioned Review of Philanthropy in UK Higher Education encouraged UK universities to grow a 'culture of philanthropy' (HEFCE, 2012: 8), based on enhanced student experience and the creation of an affinity towards the institution. To enable this, the successor Workforce Review calls for 'increasing professionalism within HE fundraising' (HEFCE, 2014: 14) and a greater role to be played by 'institutional peer groups' in 'facilitat[ing] shared training and networking within a community of practice' (HEFCE, 2014: 15).

However, in spite of references to 'peer networks' and 'communities of practice' within the Workforce Review (HEFCE, 2014: 11, 43), there has been little engagement in either the policy or scholarly 
literature with the work of non-academic professional networks within the HE sector, and limited debate on the extent to which they facilitate collective learning and the sharing of knowledge within, and beyond, institutional boundaries. Whilst geographers have considered knowledge circulation within the established domains of academia (Jöns, 2008, 2009; Taylor et al., 2008; Larner, 2015) and law and advertising (Faulconbridge, 2007a, b), the sharing of knowledge amongst this subset of non-academic HE professionals, to facilitate their role as intermediaries between academic and donor, has received far less attention. Given the recent transformations in the UK - most notably, English - HE policy landscape, and the increased necessity for universities to engage in philanthropic fundraising in order to fulfil their institutional mission (Huggins and Johnston, 2009; Warren et al., 2014), this represents a significant omission. In this paper, we commence by highlighting the related literatures on the changing geographies of professional networks and learning, and on neoliberalisation and competition among UK universities. We proceed, through an empirically-informed study of UK universities established during the 1960s, to consider the role of professional networks and, less formally, peer groups ${ }^{1}$ in facilitating 'collective learning' (Faulconbridge, 2007a: 965) across spatial scales. We explore the cross-institutional nature of these associations, where interaction may be virtual as well as face to face, and where professionals navigate the tensions between inter-institutional competition with other universities and the advantages of exchanging knowledge in a spirit of cooperation with peers within those institutions.

\section{UK Higher Education: professional networks and institutional change}

\section{Emerging HEI professional networks}

In his study of networks of learning in London and New York's advertising and law clusters, Faulconbridge (2007a, b) drew attention to the importance of social relations in forging professional associations, arguing that geographies of learning and knowledge were not necessarily defined by 'scale-

\footnotetext{
${ }^{1}$ Although overlaps exist, we draw a distinction in this paper between 'professional networks' (formal or semiformal associations with a defined membership, recognised terms of reference and prescribed whole group meetings) and 'peer groups' (largely informal associations of individuals working in the same field, communicating on an ad-hoc basis, with no formal meetings or recognised agenda).
} 
based delimitations such as local-global', often differentiated as 'urban buzz' of localised knowledge creation and global 'pipelines' of knowledge 'flow' (Faulconbridge, 2007b: 1652, 1636; Bathelt et al., 2004; Benneworth and Hospers, 2007). Instead, drawing on the work of Amin and Cohendet (2004) on the development and transaction of knowledge, Faulconbridge posited that professional networks should be recognised as 'contested, fluid and dependent on the spatial organisation of learning practices' (2007b: 1652).

Within such settings, knowledge exchange is facilitated among professionals employed by different firms on matters such as challenges faced (and their solutions), practices within a specific marketplace, client service provision, and personal aspirations and advancement (Faulconbridge, 2007b). This capacity for collective learning is arguably enhanced by 'institutional thickness' (Amin, 1999), in which supportive social, cultural and institutional arrangements (for example, training agencies, chambers of commerce) facilitate ‘dialogue and learning based on shared knowledge and information exchange’ (Amin, 1999: 370-371; Keeble et al., 1999). Within these networks, members exchanged 'tacit knowledge', that is, learning that cannot necessarily be codified (Faulconbridge, 2006; Gertler, 2003; Lawson and Lorenz, 1999). Sociologists have argued that these forms of knowledge enable professionals to exert 'social and cultural control' in an 'exclusive' way (Abbott, 1988: 86; Evetts, 2003). As such, according to Bourdieu, tacit knowledge represents a form of 'social capital' which comprises the 'aggregate of the actual or potential resources which are linked to [...] membership in a group’ (1986: 248). It lends itself not only to the activities of professional service firms, but also to the transfer of know-how within technical communities (Bagchi-Sen et al., 2004; Saxenian and Hsu, 2001), including the oil exploration industry (Bridge and Wood, 2005). These studies recognise the complexities inherent in the changing geographies of knowledge and call for further examination of their embeddedness within professional settings.

Within the context of HEIs, investigations by geographers into the spatialities of collective learning via professional networks have largely been confined to studies of those employed in academic positions (Jöns, 2008, 2009; Solem and Foote, 2004; Wakefield, 2013). Jöns, for example, drew attention to the 
role of academic travel in the development of the University of Cambridge and its part in supporting new knowledge claims, importing ideas, raising funds and intensifying academic networks, all of which resulted in the creation of new 'geographies of knowledge, science and higher education' (2008: 362). The changing nature of academic work, and the transformation of the academic profession due to 'mass higher education', has been considered in the education studies literature by Scott (2006: 19), who argued that the consequent wider distribution of academic knowledge within a technologically advanced 'knowledge society' made it possible for researchers to establish 'more complex, much more instantaneous and much more robust networks' (2006: 25). Moreover, the author cited the need for academics to function as research managers, entrepreneurs, teachers 'and (even) sales and marketing people’ (Scott, 2006: 24; Whitchurch, 2009). Building on this observation, Middlehurst subsequently noted the emergence of academics as 'hybrid professionals' (2009: 236), utilising a combination of different skills which cut across professional boundaries. Yet, although Daly has studied the roles assumed by Development Directors in UK HEIs, and their cultivation of professional identities, there has been little investigation into the personal and professional networks used by these 'new professionals' (2013: 22) to facilitate collective learning in a rapidly changing and competitive HE environment.

\section{Institutional change: collaboration and competition among UK universities}

The emergence of the HEI philanthropy professional has coincided with a period of increasingly neoliberal transformation of the HE funding environment, with UK universities expected to take far greater responsibility for their financial futures (DfES, 2003). Yet, whilst the financialisation of HE has become a source of preoccupation for geographers and policy studies scholars (Ball, 2012; Engelen et al., 2014), much of the debate has focused on critiquing neoliberal expectations that HEIs ought to support the requirements of the contested 'knowledge economy', permitting host countries to compete more effectively in the global marketplace of ideas and innovation (Etzkowitz, 2012; Goddard and Chatterton, 1999; Rye, 2014; Thiem, 2009). Within this knowledge economy paradigm, education has been seen as fundamental to the creation of 'neo-liberal and global citizen-subjects' (Thiem, 2009: 155; Hall, 2011), whereby discourses of work, knowledge and competencies are given precedence over belonging and 
cross-cultural ties. Scholars have thus drawn attention to, and critiqued, neoliberal expectations that HEIs align their teaching and research to the needs of industry, and engage in collaborative activities such as ‘joint-research partnerships’ with public and private actors (D’Este and Iammarino, 2010: 335; Lawton Smith et al., 2014), development of industrial clusters (Comunian and Faggian, 2014; Lawton Smith, 2007) and creation of joint education and training programmes (Thiem, 2009; Waters and Leung, 2013).

At the same time as undertaking such collaborative ventures, HEIs are evermore in competition with one another for funding via research grants and contracts, academic staff and, increasingly, students. This rivalry has arguably exacerbated existing 'uneven' geographies of HE provision and development (Altbach, 2004). As a consequence, physical location and a sense of 'embeddedness' within a locality or region, has contestably become less important for the older civic universities seeking to thrive in the global marketplace (Goddard et al., 2014: 11; Cochrane and Williams, 2013). Moreover, this nexus between competition and collaboration within the HE sector has, argued Jöns and Hoyler (2013), been reflected in the production of national and international university rankings. For example, academic mobility, within the longstanding THE-QS rankings, has been perceived as both enabling international research collaboration, and as a measure of institutional competitiveness (Jöns and Hoyler, 2013: 56). According to Castree, this situation generates ‘competitive collaboration’ (2006: 750), whereby receipt of research funding is increasingly conditional on joint working amongst universities, which at the same time compete for staff, students and other resources. Arguably, aspects of the work of the non-academic HE professional - located within a university, yet seeking to cooperate with, and learn from, colleagues in competing institutions - embody this contradiction.

Development Directors, argued Daly, adopt ‘cross-boundary professional identit[ies]' when liaising with HEI managers and academics (2013: 28). As such, they occupied multiple roles, involving elements of fundraising (or 'development'), alumni relations, communications, marketing and research (HEFCE, 2012). Within this context, the philanthropy professional is expected to deploy strategic vision, share social capital and secure the support of the senior management team (Daly, 2013). In this paper, we bring 
together the three literatures on professional networks, university neoliberalisation and 'hybrid' professionals within HE. In doing so, we consider the challenges encountered by HEI philanthropy professionals in forging a distinct identity within their institution, and the extent to which their professional status has been shaped through interactions with peer networks.

\section{Methods}

Our empirical research comprised interviews with Development Directors, or equivalent, at selected 1960s universities (Table 1). The 1960s universities were chosen as they had been founded during a period of considerable national expansion of HE provision and lacked the tradition of endowment or philanthropy which supported Oxford, Cambridge and the older 'Civic' universities (Proper 2009). Within these institutions, the role of Development Director had largely emerged from the late 1990s onwards. The 1960s universities vary in terms of subject specialism, home and international student intake, institutional culture and academic reputation. They also have disparate geographies, being located in a variety of urban, suburban and rural contexts across England, Scotland and Northern Ireland. These institutions comprise two main groups. Firstly, the nine foundations - known as the 'Plateglass universities’ (Beloff, 1968) - established by the UK government and granted degree awarding powers from the outset (universities of: Sussex, York, East Anglia, Essex, Lancaster, Kent, Warwick, Stirling and Ulster). Secondly, the ten Colleges of Advanced Technology (CATs), originally designated as technological universities. At the time of our investigation, eight former CATs remained: Aston, Bath, Bradford, Brunel, City, Loughborough, Surrey and Salford. We approached all seventeen institutions and interviewed Development Directors, or equivalent senior staff, at fourteen HEIs. In addition, we also spoke to a small number of other senior philanthropy staff employed at selected institutions. As a result, seventeen HEI philanthropy professionals were interviewed in total. Interviewees were educated almost all to degree or postgraduate level, and the majority had been employed in arts, charitable or corporate / retail sales sectors prior to entering HEI philanthropy. Individual experience of HE fundraising ranged from five to 25 years. The meetings were between 40 and 90 minutes’ duration. We sought information on: professional background / status of interviewee; their engagement with professional networks, and the 
kinds of knowledge exchanged within those settings; the role of place and the importance of the physical location of HEIs; and the extent to which their institutions had developed a 'culture of philanthropy'. In this paper, we focus on the role of professional networks.

***Insert Table 1 approximately here***

All interviews took place between April and July 2014, with the majority comprising face to face meetings. Where this was not possible, discussions were conducted via Skype or telephone. Interviews were recorded where permission was granted, and then transcribed. The interview data were analysed following the logic of grounded theory (Glaser and Strauss, 1967) and with reference to the key themes identified in the scholarly literature. Each text was independently assessed by two of this paper's authors to identify areas of significance for participants. By this process, we were able to identify key themes on the role of professional networks in shaping the development of senior HEI fundraisers. Illustrative quotes were extracted from the transcripts. In order to maintain anonymity, the identities of the interviewees and their affiliations have not been revealed ${ }^{2}$.

\section{From professional networks to 'the profession'}

Formal and informal networks

The philanthropy professionals interviewed participated in various formal and informal networks (Table 2). Whilst interpretations varied, interviewees indicated that the Council for Advancement and Support of Education (CASE) and the Institute of Fundraising (IoF) represented more formal networks. The former originally founded in the US, where it could trace its origins back over a century (CASE, 2014), and represented in the UK by CASE Europe - was perceived to be the main body responsible for specialised training courses and supporting HEI fundraisers:

\footnotetext{
${ }^{2}$ In addition, to avoid the possibility of linking quotes and thus identifying individuals, interviewees have not been assigned labels.
} 
I think [CASE] are fantastic at providing training and also if you want it when you're presenting or doing papers, if you need any stats or anything, they've got a fantastic research centre in [Washington] DC which is very helpful, so I find them a fantastic resource.

***Insert Table 2 approximately here***

Arguably, within the domain of $\mathrm{HE}$, this bespoke training also represented a means of ensuring exclusivity over the performance of specific practices and the dissemination of knowledge (Abbott, 1988; Faulconbridge and Muzio, 2012; Hall, 2009). The IoF, established in 1983, had a much broader remit, representing the UK charity sector as a whole. As such, its focus was perceived by some interviewees to be more on large-scale direct mail campaigns and the recruitment of significant numbers of lower level regular givers. In addition, the IoF was seen to play an important advocacy role. The interviewee below drew attention to the distinction between the work of CASE and the IoF:

If it's a technical matter like tax exempt status or something like that, I'll go to either the Institute of Fundraising or HMRC, but if it's kind of operational or should I be doing this, I use CASE and my professional network.

The professional networks most frequently mentioned by interviewees were the Ross Group and the Development Directors' Forum. Both networks served the needs of the UK HEI senior philanthropy professionals and performed formal and informal functions (Bathelt and Cohendet, 2014). The Ross Group, an invitation-only membership organisation which emerged during the late 1990s, generally recruited Directors from well-established UK universities with a high financial turnover and considerable experience of overseeing the receipt of significant gifts. The Development Directors' Forum, founded approximately half a decade later and of which the majority of interviewees claimed membership, largely 
comprised institutions from the former 1994 Group of smaller research intensive UK universities ${ }^{3}$, which itself had been set up following the establishment of the Russell Group of large research intensive HEIs. Although opinion among the interviewees varied, it appeared that the Development Directors' Forum was, like the Ross Group, self-selecting. In case of both Groups, similarity amongst institutions was seen as essential to their purpose:

The Ross Group is an odd group. It’s jolly. It’s not really intended to be, in my view, anything more than a dining club. It's a group based on individual membership. So I think it is effective at openly sharing the pain of where you are, behind closed doors.

Basically [the Development Directors' Forum] [is] an invite based on the person. So, we're HE professionals, we're the guys who aren't in the Ross Group effectively.

The two Groups functioned through a mix of formal face to face meetings, usually held twice a year, where members sat around a table, and informal networking where less well-defined, 'tacit', knowledge was shared via telephone conversations and emails (Gertler, 2003). This formal / informal binary was deemed to be essential to the performance of both Groups:

...so we have formal meetings of [the ex-1994] Group, but it's the informal network where the real value comes from. So I pick up the phone and ring one of them [...]. So, that's where I go. [...] I'm fairly certain if I were to ring up almost anybody, then they would give me a sensible answer, it is a very collegiate profession.

Although the meetings represented planned encounters between previously familiar parties, the informal nature of networking amongst members supports Bunnel and Coe’s contention that knowledge production

\footnotetext{
${ }^{3}$ Although the 1994 Group of UK universities disbanded in November 2013, interviewees generally referred to this network as the ‘1994 Group’, the ‘ex-1994 Group’ or, occasionally, the ‘group with no name’.
} 
involves ‘complex and evolving integration [...] across various spatial scales simultaneously’ (2001: 570). Moreover, it is indicative of Grabher's (2001) perspective that forms of social organisation (conceptualised as 'heterarchies') learn from rival organisations as well as from colleagues. These practices, as Amin and Cohendet argue, debunk the notion that 'knowledge falls into bundles organised along neat geographical scales’ (2004: 86). Yet, the exclusionary nature of the Ross Group, in particular, appeared to act as a barrier to knowledge exchange, causing frustration amongst certain interviewees:

So the shadowy cabal that is the Ross Group, you can quote me on that as well if you like, that has no established criteria for membership and appears to be done by handshakes under the table, is [a] self-appointed elite and doesn't have the complete faith of everyone in the sector. [...] it is interesting to note how few of the 1960s universities have a representative on the Ross Group, and there are some very good people running the 1960s universities.

I think the Ross Group is a closed shop, the membership of which is unknown, what they discuss is unknown. Membership is by invitation, which considering they are seen as a group representing HE, and if the press want to quote a group they will quote this group, but that group is not representative of the field. My opinion is that that is wrong...

Although Bathelt and Glückler (2011) drew attention to the dangers of social relationships at the local scale becoming too rigid and too close - and Glückler (2014) wrote about the potential of controversial innovation from the periphery - less consideration has been given by geographers to practices of exclusivity within professional sectors, and the attendant frustrations they may engender in excluded parties (Abbott, 1988; Faulconbridge, 2007b). In the case of the HEI philanthropy workforce, the exclusive membership of the Ross Group - based on 'elite' institution type rather than professional status - was perceived to stymie the professional development of uninvited Development Directors employed at 1960s HEIs. Nevertheless, as one interviewee suggested, restrictions on membership were deemed necessary to permit frank discussions on specific topics - to 'openly shar[e] the pain of where you are 
behind closed doors' - for instance, regarding the acceptance of gifts or, more generally, cultural issues surrounding fundraising in specific environments. As such, the selective nature of these networks enabled institutional professionals to mitigate risk inherent in particular practices of philanthropy, a live concern following the publication of the Woolf Report into the London School of Economics' (LSE's) links with Libya (Woolf, 2011) ${ }^{4}$.

Finally, Development Directors utilised looser, informal networks, often comprising personal contacts made during the course of their career. These individuals were mentors, ex-colleagues or overseas professionals met during study tours ${ }^{5}$. The bonds within these groupings therefore tended to be long established, often forged at the beginning of an interviewee's career, and the knowledge shared by individuals was often imbued with unconscious, sometimes personal, content (Gertler, 2003). Within these networks, practices of knowledge sharing were naturally more fluid:

I went on that first year of that [CASE organised] trip to [North American location] as it was then. That whole cohort of people, who had all either been good or been promoted, is my learning group, really. So if I'm needing any personal advice, particularly anything strictly confidential, that's the group I ask things of.

Unlike local 'buzz', sharing within these informal networks transcended scale, with knowledge being exchanged on the basis of common practices, informed by individuals' experiences, a process referred to by Blanc and Sierra as 'relational proximity' (1999: 197). These arrangements facilitated the communication of tacit knowledge on a trusted basis on topics such as starting a fundraising campaign, promoting philanthropy within the university or negotiating any cultural sensitivities when meeting

\footnotetext{
${ }^{4}$ These links included the receipt of funds by the LSE from a charity associated with the ruling Gaddafi family following the award of a PhD to Saif Gaddafi, son of the former Libyan leader Muammar Gaddafi, in 2008.

${ }^{5}$ CASE Europe, for example, run study tours most years to allow its members to learn about the philanthropic fundraising practices of universities and colleges located in North America.
} 
potential donors. The confidential nature of these problems meant that they could not be discussed within formal settings, or even with colleagues from similar institutions who might be deemed to be competitors.

\section{Shared learning and competitive advantage}

Interviewees reported on the open, even friendly, nature of the UK HEI philanthropy profession, with counterparts in other universities willing to share knowledge. In part, this was due to a perceived lack of competition for alumni who, if awarded degrees from more than one university, tended to display loyalty towards their first institution. One interviewee, previously employed in the private sector, drew attention to the contrasting approaches to knowledge exchange:

It's a very sharing environment because we're not in competition. The only time we're in competition with other institutions is when we're applying for trusts and foundations. [...] The environment I came from in the sales culture is you don't let anything up because you're losing an advantage.

For most interviewees, direct competition within HE fundraising was, as stated above, largely confined to applications to trusts and foundations, and the occasional solicitation of a significant individual donor. In such circumstances, information was not shared:

It's funny, for instance one of my counterparts at another university [...] we talk, we're very open and he's a brilliant fundraiser and we are very open and share things, but we know we have one common major prospect and we don’t talk about it.

At the same time, philanthropy professionals voiced concerns about changes within the broader HE policy environment, and that the current, relatively cooperative, way of working may not continue: 
And I think we're now into a new environment where people perhaps are becoming a little cagier generally because they're worried about the sense of "are we going to fall foul of competition law?"

And I suspect there will be more competition in the fundraising space as well as in the recruitment of student space, which might mean universities getting a little bit more cautious about what they will share and what they won't share.

In the first extract, the interviewee referred to the fact that UK HEIs are working in an increasingly competitive environment (a repeated refrain amongst HEI interviewees), and that HEIs could not be seen to be operating in an anti-competitive manner. Although the imperative for universities to gain competitive advantage, nationally and globally, has been investigated in the geographical literature (Jöns and Hoyler, 2013; Rice, 2011), less consideration has been given to how this rivalry has impacted on the possibilities of cooperation between HEI professionals and how any tensions that arise - for example, from competition for donors or, conversely, anxiety about UK competition law - are managed (Castree, 2006). Arguably, professional networks and peer groups have an important - and under-investigated - role to play in resolving these dilemmas (Lawton Smith et al., 2014; Waters and Lawton Smith, 2008). The second extract, above, referred more broadly to changes in UK HE policy and suggested that the ongoing neoliberalisation of the sector may result in less willingness to share practices (Daly, 2013). These policy changes raise further questions about the role of networks, and the extent to which members of even relatively exclusive groups operating in closed settings (such as the Ross Group and the Development Directors' Forum) will continue to exchange knowledge. Such exclusivity was compounded by the sector specific nature of knowledge exchange. Whilst interviewees were recruited to HE philanthropy from other domains including the arts, charities and corporate sales, little interaction appeared to occur across these sectors:

...there isn't a cross over [...] when I go to a conference, we don't have a whole mix of fundraisers there. You could see the worth in a massive fundraising conference, [where] we've got everyone 
from HE to charities to arts to sport across the mix, or have a debate with all the fundraisers from the different four areas, that would be fantastic.

Instead, interviewees suggested semi-formal networks (such as the Ross Group and Development Directors’ Forum), and personal contacts within HE, played an important role in gathering knowledge about the fundraising set-up in other UK HEIs, within and beyond the group.

I think that's something about the openness of the profession, if you want to call it a profession, that we do share both best and worst case practice.

I've been the recipient of some advice from a couple of organisations, especially when we started this fundraising appeal. I wanted to put the feelers out, but very informally though, just using the mail-based group as a way of communicating.

As suggested in both extracts, above, this process was deemed to be particularly helpful as it enabled Directors to benchmark informally the progress of their own institutions. In part, the use of networks and other peer groups - such as mailing lists mentioned by the second interviewee - is unsurprising given the isolated nature of the Director of Development's role within the university. The perceived loneliness of the post was ostensibly the spur for one individual to co-found one of the professional networks:

I literally phoned up people and said: Hello, I’m [name]. Can I come and see you? [...] by doing that, I created a network and it dawned on me when I've got a problem it's nice to talk to somebody. It's a very lonely job because nobody else in the university understands my worries. [...] we've got two and a half thousand staff and probably apart from my deputy I've got nobody to talk to who generally gets it. 
The impetus to establish a peer network which transcended the specific location of the employing institution, is significant. Whilst other studies, for example, work on high technology professionals in local economies, have indicated that networking activity amongst highly skilled workers may be less common than generally assumed (Waters and Lawton Smith, 2008), where professional associations do exist, there has been a lack of scholarly research detailing the actual process of network formation.

At the same time, our fieldwork indicates that individuals were not averse to circumventing existing or emerging networks when seeking comparative information beneficial to their institution:

We obviously look at the benchmarking data when it comes out and I've been doing a lot of comparing with kind of the more established universities and where they are, and they're primarily Russell Group universities. But I have friends who work in Russell Group institutions, so I would speak to them, but yes I certainly don’t tap into their directors’ network.

This individualistic practice is suggestive of one response by practitioners to working in an environment which is cooperative yet also competitive. Equally, the neoliberal HE landscape shaped practitioner approaches to the recruitment of staff, informed by the stated difficulty in acquiring, and then retaining, experienced fundraisers. This recruitment and retention 'problem', highlighted in the Workforce Review (HEFCE, 2014), was exacerbated by location, as reported by an interviewee based in the Midlands:

I think that's a challenge with our location, I think the London universities, I think there's a lot of mobility around them and the charitable sector, and the number of universities there, if somebody's going to move to [interviewee's institution] for a fundraising role that's probably unlikely unless their partner is moving ...

In the case of recruitment, professional networks served as a valuable resource for dissolving some of the spatial barriers to attracting new staff. For example, the networks provided a forum for discussion on 
what one Development Director referred to as 'recruitment, staffing issues' and, we contend, a source of information on skilled staff already employed within the HE marketplace. More structured professional networks such as CASE also played a role in securing employment for the philanthropy workforce, and the annual CASE Europe conference was seen by interviewees to serve as an informal recruiting event ('a bit of a job shop really’).

We argue, therefore, that individual professionals used their networks to make informal connections with prospective employees in the sector (Cook et al, 2012; Faulconbridge et al, 2009). In a setting where universities were competing intensely for staff, these networks (formal and less formal) performed disparate roles. Working across institutional and scalar boundaries, they facilitated collective learning and - through fora such as events run by CASE - appraisal of prospective employees. At the same time, Directors reported operating on occasion beyond these groups and engaging directly with individuals in other HEIs when seeking to augment the philanthropy expertise within their own institution.

\section{Professional identities in blended environments}

We contend that the work of the professional networks - formal and informal - facilitated the emergence of a 'new' HEI professional. Granted, there was no single professional model, and indeed Development Directors spoke of personal styles of working. Nevertheless, the skills mentioned, or suggested, by interviewees were suited to the HE philanthropic environment, and certain attributes were regarded as essential in order to operate effectively. In particular, the Development Directors stressed the need for senior postholders to have a strategic vision supported by long term planning. As such, in order to develop a culture of philanthropy - and the HE philanthropic profession - it was important that university fundraising was integrated within the broader institutional strategy:

One of the most gratifying things has been that the university has just launched its new strategic plan for the next five years, and for the first time ever engagement with alumni and friends of the university and fundraising is featured very prominently in that strategy. 
Within the 1960s universities, this appeared to be a recent development. Some interviewees described how, when appointed to their current post, there had been a lack of strategic vision for philanthropy coming from the institution. Moreover, interviewees acknowledged that strategic alignment of philanthropy with university goals was a long term process (HEFCE, 2012):

It always takes a couple of years to start to help people understand which projects will best support the strategic goals of the institution. And if the strategic direction of the university's a bit vague that's quite a difficult thing to do.

This needs to be embedded in all major corporate publications so that people see that this is a strategic priority for the university, not for the development office, for the university. So I always like talking in terms of the university rather than us [...]

The fact that professionals were beginning to make an impact in this area indicated their increased influence in informing and shaping philanthropic fundraising in UK universities, to the extent that the outcomes were being broadcast in institutional publications including recruitment, research and graduation brochures (Warren and Bell, 2014). To return to the second professional quoted above:

... to me the fact that we had the buy-in, especially from the senior management of the university in that area to get the commitment in terms of time and energy [...], because to me one of my key comments in terms of the strategy was that we needed to make sure the impact of philanthropy was embedded in all our communications

This enhanced social capital (Waters and Lawton Smith, 2008) had been achieved through extensive internal networking and partnership working across the institution. Although the professional networks discussed in this paper were important in advancing knowledge on fundraising to peer groups in other 
universities located across the broader HE community, their role in assisting Directors to promote philanthropy within institutions was less well articulated by interviewees. Whilst one Director mentioned discussion of 'making a business case within your institution' at a meeting of the Development Directors' Forum, success in raising the status of fundraising within the university was generally the result of an individual's work within the institution. For instance, an interviewee who had moved to HE from the charitable sector noted the difference in 'the position of the fundraising team within the institution', with university development teams generating a much smaller percentage of the institution's turnover. This lack of equivalence across HE and charitable domains, compounded by the small number of fundraising staff employed within HEIs, necessitated greater reliance on networks for knowledge exchange and to secure a professional status (Abbott, 1988). However, interviewees also stressed the need for a direct reporting line to the Vice-Chancellor, coupled with a presence on high level committees, in order to raise awareness of philanthropy. As one longstanding Director of Development stated:

...the thing that has been missing is the direct line. And it's still unusual in the UK. It is absolutely ubiquitous in North America. The advancement senior officer reports to the president. You're vice president as advancement. [...] It needs to come in the UK.

Whilst the UK philanthropy professionals interviewed did not occupy boardroom positions, the standing of senior development staff - due to enhanced internal social capital - was beginning to improve. Fundamental to this outcome was the ability to develop trust and build conviction within the academic community. According to Daly, philanthropy professionals needed to adopt 'cross-boundary professional identit[ies]' (2013: 28), influencing HEI senior management to ensure that philanthropy was written into the job description of newly appointed senior academics:

I think the most critical thing to do is to integrate philanthropy within academic planning [...]. So if when you recruit a new dean of school - important academic - if you're not within your search criteria, if you're not front loading aptitude, attitude, experience in fundraising and if it never comes 
up in the interview you're probably very unlikely to appoint somebody that - now that's not necessarily a disaster, but...

In addition, certain interviewees - aware of limited resources for travelling to meet potential donors were engaging smartly with academics:

...we can't go [to the US] every five minutes. So what if we track down all of our academics who are going over to the States and say, Professor $\mathrm{X}$ is going to be in Manhattan on the 3rd June, he'll be at so and so bar. If you want to go and join him for a drink he'll be delighted to share with you some of the exciting things. And that is starting to work.

In this extract, the interviewee was able to build philanthropy into an academic's overseas research visit, seeking to match researcher interests with those of a potential donor. Granted, interviewees reported that not all academics would be suited to meeting with donors and, indeed, the extent to which this type of engagement was pursued would be dependent on the personal style of the Director. Nevertheless, willingness to innovate was seen as one component of the increasingly varied attributes expected of philanthropy professionals, and one which could result, in the words of one interviewee, in the emergence of a new role, namely 'academic champions', high profile researchers who promote fundraising within an institution. Whilst some of the practices deployed by these professionals could be taught - initially by attending events organised by more formal professional networks such as CASE and the IoF - many appeared to have either been learnt 'on the job', or through discussions with colleagues in other HEIs and mentors. In the latter case, professional networks - for this cohort of senior professionals - acted as private spaces of communication, enabling individuals from similar sized universities to share knowledge of personal experiences of problems specific to their institution. Hence, the importance of belonging to relatively small networks such as the Ross Group and the Development Directors' Forum, where knowledge could be exchanged easily, either amongst the whole group at formal meetings, or less formally, between individual members. As one interviewee 
remarked, the Development Directors’ Forum, 'it is essentially a self-help group for people facing similar challenges.’

At the same time, mentoring served a useful purpose in enabling professionals to seek knowledge from a respected individual on a one-to-one basis. In this relationship, the sharing was one-way, with the interviewee's career development benefiting from the knowledge and experience of a senior professional from outside the institution. The mentors were often 'high level' individuals - sometimes employed at Russell Group universities or as consultants - who had supported the Development Directors from the early stages of their career, and were able to be called on to assist with specific operational matters which the interviewee wished to remain 'strictly confidential'. Often this communication was virtual and occurred strictly on the basis of need. In the words of the same Director, when discussing the availability of their mentor: 'I can pick up the phone and talk to her if I need to'. Therefore, in addition to adopting a multi-faceted role, development professionals worked in an environment where social interaction and knowledge exchange were also 'blended', shifting between face-to-face meetings, email contact and telephone conversations (Maintz, 2008).

\section{Discussion and conclusion}

Our investigation has highlighted how a series of interrelated networks have enabled this 'emerging profession’ of university Development Directors to transcend their spatially fixed institutional settings and exchange knowledge in multi-scalar spaces with individuals employed in other HEIs. In doing so, our evidence suggests that Development Directors have enhanced their skills and capacity to deliver their university’s mission. We draw attention to three ways in which our empirical work advances theoretical research on knowledge exchange among HE professionals.

First, professional networks were stratified, with some established as a response to changes in the UK HE landscape. We argue that the power of these groups has been underplayed by UK policymakers (HEFCE, 2012, 2014). Although CASE and the IoF are relatively well established, much of the collective learning 
described by senior professionals occurred within semi-formal networks such as the Ross Group and the Development Directors’ Forum. The latter groups were exclusive. Unlike other professions studied by geographers, such as law and advertising (Faulconbridge, 2007a, b), invitation to the key networks was determined largely by the size and turnover of the employing university. Whilst this circumstance generated resentment amongst some non-members, there was a degree of fluidity, with admissions to the Ross Group and the Development Directors' Forum adapting to perceived shifts in 'hierarchies of learning', reflected, for example, in positioning within university league tables and membership of associations, such as the Russell Group (Rice, 2014). Both professional networks acted semi-formally, combining meetings of the full membership with ad-hoc one-to-one virtual contact. As such, these networks enabled professionals to respond in an agile manner to work-related problems as they arose, and acted as private spaces of communication through which individuals could exchange tacit knowledge, as well as strategies and experiences, on a confidential basis across spatial scales. Development Directors therefore engaged in practices of 'relational proximity’ (Blanc and Sierra, 1999: 197), with sharing of knowledge more closely tied to their professional role, and institutional 'type', than to spatial setting. Although divergences in the architecture of professional groups have been highlighted by scholars (Bridge and Wood, 2005; Faulconbridge, 2007a, b; Saxenian and Hsu, 2001), our research sheds important light on the uneven operation of networks within this sector from the perspectives of both participants and (excluded) non-participants.

Second, in spite of the increasingly competitive nature of UK HE, and the pressures on philanthropy professionals to raise revenue for their institutions, the sharing of knowledge within professional networks was open, relative to other professions (Abbott, 1988; Faulconbridge, 2007a). Granted, certain activities - such as bids to trusts and foundations - were not discussed among individuals. Moreover, interviewees indicated that the continuing neoliberalisation of the UK HE sector, and the attendant focus on the global positioning and ranking of institutions, may inhibit knowledge exchange activities (Daly, 2013; Whitchurch, 2009). We argue that - within closely bound settings of networks such as the Ross Group and the Development Directors’ Forum - knowledge continued to be shared extensively among 
professionals from rival institutions, across the UK, on practices such as approaching potential donors from different countries, drafting gift acceptance policies and handling staffing and recruitment matters. Much of the work within these networks was therefore cooperative, with members seeking to gain expertise in order to become more effective practitioners, better equipped to deliver on their institution's fundraising priorities. Development Directors, accordingly, acted not only as intermediaries (between academic and donor) but equally as facilitators. In addition, these professionals collaborated, in the sense of working together to achieve specific goals, for example, in the training of new entrants and in the promotion of the profession. Our identification of the subtleties underlying these interactions, among professionals in similar universities - which also compete for staff, students and research funding advances the debates on ‘competitive collaboration’ across the HE sector in novel ways (Castree, 2006: 750).

Third, professional and peer networks provided HEI philanthropy staff with knowledge to generate a distinctive professional identity. As Development Directors, their ability to be effective facilitators required a range of skills and knowledge honed through training and the use of networks. The isolated nature of the position - with only a small number of senior philanthropy staff employed in each institution - gave a particular significance to professional networks and geographically unbounded peer groups as sources of advice and support. These networks allowed Development Directors to assume a more visible and outward facing role, transcending institutional professional boundaries, and engaging with academics and senior HEI management. Although geographers have investigated the imagining and maintaining of professional communities across spatial scales, the role of these groups in enabling members to establish a professional identity within their institution has been less well documented. In this paper, we have therefore uncovered the influence of networks on the development of HEI Development Directors as skilled professionals with multiple capabilities (Daly, 2013; Middlehurst, 2009). Our empirical research suggests that philanthropy professionals exploited the opportunities offered by a 'blended' environment to enhance their skills, knowledge and confidence through both the physical attendance at meetings and virtual communication - via telephone, email and online message boards - which extended beyond the 
locality in subtle and important ways. As the universities in our sample were not spatially clustered, the deployment of both means of communication ensured that practices of knowledge exchange and learning amongst professionals were not inhibited by a lack of institutional proximity. This mobilisation of personal connections across geographical scales (Hall, 2011), in order to create, maintain, and further enhance, professional knowledge, suggests an alternative framing of the operation of professional networks as open spaces of learning which are less defined by territory, or institutional belonging, and more bound in organisational homogeneity across spatial scales.

\section{References}

Abbott A, 1988, The System of Professions: An Essay on the Division of Expert Labor (The University of Chicago Press, Chicago)

Altbach P, 2004, “Globalisation and the university: myths and realities in an unequal world” Tertiary Education and Management 10(1) 3-25

Amin A, 1999, “An institutionalist perspective on regional economic development" International Journal of Urban and Regional Research 23(2) 365-378

Amin A, Cohendet P, 2004 Architectures of Knowledge: Firms, Capabilities and Communities (Oxford University Press, Oxford) 
Bagchi-Sen S, Lawton Smith H, Hall L, 2004, "The US biotechnology industry: industry dynamics and policy" Environment and Planning C: Government and Policy 22(2) 199 - 216

Ball S, 2012 Global Education Inc: New Policy Networks and the Neo-liberal Imaginary (Routledge, Abingdon, Oxon)

Bathelt H, Cohendet P, 2014, “The creation of knowledge: local building, global accessing and economic development - toward an agenda” Journal of Economic Geography 14(5) 869-882

Bathelt H, Glückler J, 2011 The Relational Economy: Geographies of Knowing and Learning (Oxford University Press, Oxford)

Bathelt H, Malmberg A, Maskell P, 2004, “Clusters and knowledge: local buzz, global pipelines and the process of knowledge creation” Progress in Human Geography 28(1) 31-56

Beloff M, 1968 The Plateglass Universities (Fairleigh Dickinson University Press, Madison, NJ)

Benneworth P, Hospers G, 2007, “The new economic geography of old industrial regions: universities as global-local pipelines” Environment and Planning C: Government and Policy 25(6) 779-802

Blanc H, Sierra C, 1999, “The internationalisation of R\&D by multinationals: a trade-off between external and internal proximity” Cambridge Journal of Economics, 23 187-206

Bourdieu P, 1986, “The forms of capital”, in Handbook of Theory and Research for the Sociology of Education Ed J Richardson (Greenwood, New York) pp 241-258 
Bridge G, Wood A, 2005, “Geographies of knowledge, practices of globalization: learning from the oil exploration and production industry” Area 37(2) 199-208

Bunnell T, Coe N, 2001 “Spaces and scales of innovation” Progress in Human Geography 25(4) 569_ 589

Cabinet Office, 2011 Giving White Paper Cm 8084 (The Stationery Office, London)

CASE (Council for the Advancement and Support of Education), 2014 “CASE History” http://www.case.org/About_CASE/CASE_History.html\#pred Accessed 16/03/15

Castree N, 2006 “Research assessment and the production of geographical knowledge” Progress in Human Geography 30(6) 747-782

Cochrane A, Williams R, 2013 "Putting higher education in its place: the socio-political geographies of English universities” Policy and Politics 41(1), 43-58

Comunian R, Faggian A, 2014, "Higher education, human capital, and the creative economy" Environment and Planning C: Government and Policy 32(3) 381-383

Cook A, Faulconbridge J, Muzio D, 2012 “London’s legal elite: recruitment through cultural capital and the reproduction of social exclusivity in City professional service fields” Environment and Planning A 44(7) 1744-1762

Daly S, 2013 "Philanthropy, the new professionals and higher education: the advent of Directors of Development and Alumni Relations” Journal of Higher Education Policy and Management 35(1), 21-33 
D’Este P, Iammarino S, 2010 “The spatial profile of university-business research partnerships” Papers in Regional Science 89(2), 335-350

DCSF (Department for Children, Schools and Families), 2007 “£600 Million Boost to be Generated for Higher Education Fundraising” Press Notice, 2007/0026 15 February

DfES (Department for Education and Skills), 2003 The Future of Higher Education Cm 5735 (The Stationery Office, London)

DfES, 2004 Increasing Voluntary Giving to Higher Education: Task Force Report to Government (DfES, Nottingham)

Engelen E, Fernandez R, Hendrikse R, 2014, “How Finance Penetrates its Other: A Cautionary Tale on the Financialization of a Dutch University” Antipode 46 1072-1091

Etzkowitz H, 2012, "Triple helix clusters: boundary permeability at university-industry-government interfaces as a regional innovation strategy" Environment and Planning C: Government and Policy 30(5) $766-779$

Evetts J, 2003, “The sociological analysis of professionalism: Occupational change in the modern world” International Sociology 18(2) 395-415

Faulconbridge J, 2006, “Stretching tacit knowledge beyond a local fix? Global spaces of learning in advertising professional service firms” Journal of Economic Geography 6(4) 517-540 
Faulconbridge J, 2007a, “Exploring the role of professional associations in collective learning in London and New York's advertising and law professional-service-firm clusters” Environment and Planning A 39(4), 965-984

Faulconbridge J, 2007b, “London's and New York's Advertising and Law Clusters and their Networks of Learning: Relational Analyses with a Politics of Scale?” Urban Studies 44(9) 1635-1656

Faulconbridge J, Beaverstock J, Hall S, Hewitson A, 2009, “The 'war for talent': The gatekeeper role of executive search firms in elite labour markets” Geoforum 40(5) 800-808

Faulconbridge J, Muzio D, 2012, “Professions in a globalizing world: Towards a transnational sociology of the professions” International Sociology 27(1) 136-152

Gertler M, 2003, “Tacit knowledge and the economic geography of context, or the undefinable tacitness of being (there)” Journal of Economic Geography 3 75-99

Glaser B, Strauss A, 1967 The Discovery of Grounded Theory (Aldine, Chicago, IL)

Glückler J, 2014 "How controversial innovation succeeds in the periphery? A network perspective of BASF Argentina” Journal of Economic Geography 14 903-927

Goddard J, Chatterton P, 1999 “Regional Development Agencies and the knowledge economy: harnessing the potential of universities” Environment and Planning C: Government and Policy 17(6) 685-699 
Goddard J, Coombes M, Kempton L, Vallance P, 2014, “Universities as anchor institutions in cities in a turbulent funding environment: vulnerable institutions and vulnerable places in England” Cambridge Journal of Regions, Economy and Society, doi:10.1093/cjres/rsu004 [Advance Access]

Grabher G, 2001, “Ecologies of creativity: the village, the group and the heterarchic organisation of the British advertising industry” Environment and Planning A, 33(2) 351-374

Hall S, 2009, “Ecologies of business education and the geographies of knowledge” Progress in Human Geography, 33(5) 599-618

Hall S, 2011, "Educational ties, social capital and the translocal (re)production of MBA alumni networks” Global Networks 11(1) 118-138

HEFCE (Higher Education Funding Council for England), 2012 Review of Philanthropy in UK Higher Education Report to HEFCE (Sept) (HEFCE, London)

HEFCE, 2014 An Emerging Profession: The Higher Education Philanthropy Workforce. A Report to HEFCE by More Partnership and Richmond Associates (HEFCE, London)

HESA (Higher Education Statistics Agency), 2014a All students by HE institution 2012/13 (HESA, London)

HESA, 2014b All staff by HE institution 2012/13 (HESA, London)

HESA, 2014c Income and expenditure by HE institution 2012/13 and 2011/12 (HESA, London) 
Huggins R, Johnston A, 2009, “The economic and innovation contribution of universities: a regional perspective” Environment and Planning C: Government and Policy 27(6) 1088-1106

Jöns H, 2008, “Academic travel from Cambridge University and the formation of centres of knowledge, 1885-1954” Journal of Historical Geography 34(2) 338-362

Jöns H, 2009, “'Brain circulation’ and transnational knowledge networks: Studying long-term effects of academic mobility to Germany, 1954-2000” Global Networks 9(3) 315-338

Jöns H, Hoyler M, 2013, “Global geographies of higher education: The perspective of world university rankings” Geoforum 46 45-59

Keeble D, Lawson C, Moore B, Wilkinson F, 1999, “Collective learning processes, networking and 'institutional thickness' in the Cambridge region” Regional Studies 33(4) 319-332

Larner W, 2015, “Globalising knowledge networks: Universities, diaspora strategies, and academic intermediaries" Geoforum 59 197-205

Lawson C, Lorenz E, 1999, “Collective learning, tacit knowledge and regional innovative capacity. Regional Studies, 33(4) 305-317

Lawton Smith H, 2007, "Universities, innovation, and territorial development: a review of the evidence" Environment and Planning C: Government and Policy 25(1) 98-114 
Lawton Smith H, Chapman D, Wood P, Barnes T, Romeo S, 2014, "Entrepreneurial academics and regional innovation systems: the case of spin-offs from London’s universities" Environment and Planning C: Government and Policy 32(2) 341-359

Maintz J, 2008, “Synthesizing the face-to-face experience: e-learning practices and the constitution of place online” Social Geography 3 1-10

Middlehurst R, 2009, “Developing higher education professionals”, in Academic and Professional Identities in Higher Education: The challenges of a diversifying workforce Eds C Whitchurch, G. Gordon (Routledge, New York) pp 223-244

Proper E, 2009, “Bringing educational fundraising back to Great Britain: A comparison with the United States” Journal of Higher Education Policy and Management 31(2) 149-159

Rice G, 2011, “The ‘Browneing’ of public higher education in England” Transactions of the Institute of British Geographers 36(3) 333-337

Rye S, 2014, “The educational space of global online higher education” Geoforum 51 6-14

Saxenian A, Hsu J-Y, 2001 “The Silicon Valley-Hsinchu connection: technical communities and industrial upgrading” Industrial and Corporate Change 10(4) 893-920

Scott P, 2006, “Academic profession in a knowledge society”, in The Formative Years of Scholars Ed U Teichler (Portland Press, London) pp 19-30

Solem M, Foote K, 2004, “Concerns, attitudes, and abilities of early-career geography faculty” Annals of the Association of American Geographers 94(4) 889-912 
Taylor P, Hoyler M, Evans D 2008, “A geohistorical study of ‘the rise of modern science’: Mapping scientific practice through urban networks, 1500-1900” Minerva 46(4) 391-410

Thiem C, 2009, “Thinking through education: the geographies of contemporary educational restructuring” Progress in Human Geography 33(2) 154-173

Wakefield K, 2013 Transnational Higher Education Networks for Learning and Teaching (TNLTs) in Geography PhD thesis, Department of Geography, Loughborough University

Warren A, Bell, M, 2014, “Knowledge nodes and international networks of connection: Representations of private philanthropy and international Higher Education Institutions” Social and Cultural Geography 15(1) 49-72

Warren A, Hoyler M, Bell M, 2014, "Strategic cultures of philanthropy: English universities and the changing geographies of giving” Geoforum 55 133-142

Waters R, Lawton Smith H, 2008, “Social networks in high-technology local economies: The cases of Oxfordshire and Cambridgeshire” European Urban and Regional Studies 15(1) 21-37

Waters J, Leung M, 2013, “Immobile transnationalisms? Young people and their in situ experiences of ‘international’ education in Hong Kong” Urban Studies 50(3) 606-620

Whitchurch C, 2009, “The rise of the blended professional in higher education: a comparison between the United Kingdom, Australia and the United States” Higher Education 58(3) 407-418 
Woolf, Lord, 2011 The Woolf Inquiry: An inquiry into the LSE's links with Libya and lessons to be learned (Woolf, London) 


\begin{tabular}{|l|l|l|l|}
\hline Institution & Students $\mathbf{~ ( 2 0 1 2 / 1 3 )}$ & Staff $\left.^{\#} \mathbf{( 2 0 1 2} / \mathbf{1 3}\right)$ & Total Income \\
\hline Aston University & 9,995 & 1,900 & $117,122,000$ \\
\hline University of Bath & 15,060 & 3,345 & $208,139,000$ \\
\hline The University of Bradford & 13,195 & 2,845 & $128,364,000$ \\
\hline Brunel University London & 15,315 & 2,515 & $183,560,000$ \\
\hline City University London & 16,520 & 2,675 & $184,767,000$ \\
\hline University of East Anglia & 17,220 & 4,260 & $255,091,000$ \\
\hline University of Essex & 14,665 & 2,355 & $177,816,000$ \\
\hline University of Kent & 19,815 & 3,910 & $201,313,000$ \\
\hline The University of Lancaster & 12,740 & 3,155 & $197,839,000$ \\
\hline Loughborough University & 15,645 & 3,770 & $244,940,000$ \\
\hline University of Salford & 19,160 & 2,620 & $177,375,000$ \\
\hline University of Stirling & 10,735 & 1,995 & $104,978,000$ \\
\hline University of Surrey & 13,895 & 2,765 & $213,677,000$ \\
\hline University of Sussex & 13,145 & 3,315 & $201,752,000$ \\
\hline University of Ulster & 26,475 & 3,035 & $191,723,000$ \\
\hline University of Warwick & 26,150 & 8,085 & $459,628,000$ \\
\hline University of York & 16,150 & 4,540 & $294,701,000$ \\
\hline
\end{tabular}

Table 1: UK 1960s universities (alphabetical order)

Total all students (HESA, 2014a)

\# Includes part-time staff (HESA, 2014b)

Sources: HESA 2014a, b, c. 


\begin{tabular}{|c|c|c|c|c|c|}
\hline Network & Organisation type & Structure & Activity & Membership & $\begin{array}{l}\text { Geographical } \\
\text { reach }\end{array}$ \\
\hline $\begin{array}{l}\text { Council for } \\
\text { Advancement and } \\
\text { Support of Education } \\
\text { (CASE) Europe } \\
\end{array}$ & $\begin{array}{l}\text { Not-for-profit organisation. Funded by } \\
\text { membership fees, plus income from } \\
\text { conferences, workshops, publications, } \\
\text { awards etc. }\end{array}$ & Formal & $\begin{array}{l}\text { ‘...advocacy, networking, } \\
\text { resources, career support and } \\
\text { training opportunities...' (CASE } \\
\text { Europe, 2013: 3) }\end{array}$ & $\begin{array}{l}\text { By application. Institutional; } \\
\text { individuals can be upgraded to } \\
\text { premium membership. 'Over } 360 \\
\text { institutions' (CASE Europe, 2013: 3) }\end{array}$ & European \\
\hline Institute of Fundraising & $\begin{array}{l}\text { Registered charity and company limited } \\
\text { by guarantee. Income from membership } \\
\text { fees, training courses, sponsorship, } \\
\text { exhibitions and advertising etc. }\end{array}$ & Formal & $\begin{array}{l}\text { Focus on professional } \\
\text { development and qualifications } \\
\text { through IoF Academy. Also } \\
\text { advocacy, responding to formal } \\
\text { consultations etc. }\end{array}$ & $\begin{array}{l}\text { By application. Over 5,600 individual } \\
\text { members and } 420 \text { organisational } \\
\text { members (IoF, 2014: 3). }\end{array}$ & National \\
\hline Ross Group & $\begin{array}{l}\text { An independent, informal group of } \\
\text { experienced senior development } \\
\text { directors involved in fundraising for UK } \\
\text { higher education. Its primary function is } \\
\text { as a professional networking group. } \\
\text { Membership is by invitation of the } \\
\text { Group. }\end{array}$ & $\begin{array}{l}\text { Formal / } \\
\text { Informal }\end{array}$ & $\begin{array}{l}\text { Meet twice a year, plus } \\
\text { informal, often virtual, } \\
\text { interactions }\end{array}$ & $\begin{array}{l}\text { Invitation only. Many Russell Group } \\
\text { HEIs, plus other invited members. } \\
\text { Approx. 18-19 members. }\end{array}$ & $\begin{array}{l}\text { National (self- } \\
\text { selecting) }\end{array}$ \\
\hline $\begin{array}{l}\text { Development Directors' } \\
\text { Forum }\end{array}$ & $\begin{array}{l}\text { An independent, informal group of } \\
\text { Development Directors / Heads of } \\
\text { Development belonging to the original } \\
1994 \text { Group plus previously co-opted } \\
\text { members. }\end{array}$ & $\begin{array}{l}\text { Formal / } \\
\text { Informal }\end{array}$ & $\begin{array}{l}\text { Meet twice a year, plus } \\
\text { informal, often virtual, } \\
\text { interactions }\end{array}$ & $\begin{array}{l}\text { By application, and subject to } \\
\text { approval of existing members. Many } \\
\text { ex-1994 Group HEIs, plus other } \\
\text { invited members. Approx 16-18 } \\
\text { members. }\end{array}$ & $\begin{array}{l}\text { National (self- } \\
\text { selecting) }\end{array}$ \\
\hline Consultants & Contacts & $\begin{array}{l}\text { Formal / } \\
\text { contractual }\end{array}$ & Various contractual activities & Contractual arrangement & Varied \\
\hline Personal contacts & Unstructured & Informal & $\begin{array}{l}\text { Ad-hoc discussions / provision } \\
\text { of advice on various work- } \\
\text { related matters }\end{array}$ & $\begin{array}{l}\text { Personal contacts (mentors, ex- } \\
\text { colleagues etc) }\end{array}$ & Varied \\
\hline
\end{tabular}

Table 2: HEI philanthropy professional networks

Sources: Terms of Reference, Ross Group (personal communication, 12/03/14); Terms of Reference, Development Directors’ Forum (personal communication, 10/10/14). 